\title{
Middle and uppermost Famennian (Upper Devonian) bryozoans from southern Belgium
}

\author{
ZOYA TOLOKONNIKOVA, ANDREJ ERNST, EdOUARD POTY \& BERNARD MOTTEQUIN
}

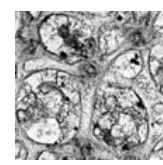

\begin{abstract}
A stenolaemate bryozoan fauna from the Upper Devonian (middle and uppermost Famennian) of the Dinant Synclinorium, southern Belgium, contains seven species (three trepostomes and four cryptostomes). One genus and four species are new: Nikiforovastylus ourthensis gen. et sp. nov., Dyscritella perforata sp. nov., Pseudobatostomella parva sp. nov., and Nikiforovella dinantia sp. nov. Three species are described in open nomenclature: Trepostomata sp. indet., Nikiforovella sp., and Rhomboporidae sp. indet. Middle Famennian Trepostomata sp. indet. shows morphology not previously recorded in Palaeozoic bryozoans. $•$ Key words: Upper Devonian, Famennian, Belgium, Bryozoa, taxonomy.
\end{abstract}

Tolokonnikova, Z., ERnst, A., Poty, E. \& Mottequin, B. 2015. Middle and uppermost Famennian (Upper Devonian) bryozoans from southern Belgium. Bulletin of Geosciences 90(1), 33-49 (8 figures, 6 tables). Czech Geological Survey, Prague. ISSN 1214-1119. Manuscript received July 7, 2014; accepted in revised form October 15, 2014; published online December 4, 2014; issued January 26, 2015.

Zoya Tolokonnikova, Kuban State University, Kazan Federal University, 353235, Aphipskiy, post box 30, Russia; zalatoi@yandex.ru•Andrej Ernst, Institut für Geologie, Universität Hamburg, Bundesstr. 55, D-20146 Hamburg, Germany; Andrej.Ernst@uni-hamburg.de•Edouard Poty, Département de Géologie, Université de Liège, Batiment B18, Sart Tilman, 4000 Liège, Belgium; E.Poty@ulg.ac.be•Bernard Mottequin, Royal Belgian Institute of Natural Sciences, O.D. Earth and History of Life, rue Vautier 29, B 1000 Brussels, Belgium; bmottequin@naturalsciences.be

Knowledge of Devonian-Carboniferous bryozoans from Belgium is based mainly on lists of fossils devoid of illustration (e.g. Maillieux 1933, Demanet 1958). Information about Devonian bryozoans from this region is thus very scarce: only a small number species from the Middle Devonian and the Frasnian have been described to date (Salée 1919; Dessilly 1961, 1967; Dessilly \& Kraüsel 1962, 1963). Their Mississippian counterparts are known from two dozen species, which are placed in the Orders Fenestrida and Cryptostomida, and were described by de Koninck (1842-1844), Demanet (1938), and Kaisin (1942). However the majority of these species remain inadequately characterised and thus has an historical value only because the descriptions were made on the external colony shape. No information about internal morphology was provided by earlier authors, and it is this that is tremendously important for the provision of detailed and accurate systematic treatments and taxonomic identifications.

Despite their great abundance in several levels of the Devonian and Carboniferous succession of Belgium (Namur-Dinant Basin), notably within the Waulsortian buildups of Tournaisian age (Lees 1988, 2006; Wyse Jackson 2006) and in some small Livian reefs (middle Viséan) (Lauwers 1992, Chevalier \& Aretz 2005), bryozoans from this area have received scant attention from specialists. As recently stressed by Ernst \& Herbig (2010), Famennian bryozoans from Western Europe remain poorly known in spite of some papers published recently (e.g. Weber \& Wyse Jackson 2006, Tolokonnikova et al. 2014). Therefore, until now, only a partial view of their diversity is available whereas there is urgent need to improve the quality of information of the evolution and renewal of bryozoan associations during this significant time interval in geological history. The Famennian was indeed marked, at its base, by the post-Kellwasser recovery and, at its top, by the Hangenberg Event that took place just below the Devonian-Carboniferous boundary (e.g. Kaiser et al. 2011).

Belgium is the historical type area of the Famennian Stage (Thorez et al. 2006), which is the youngest of the Upper Devonian. Its name originated from the Famenne region in southern Belgium and was first proposed by Dumont (1855). Although the bryozoans have been neglected so far, the other marine faunas from the area and horizon have been widely studied, notably those that can be used for regional and global biostratigraphy (Thorez et al. 1977, Poty et al. 2006), such as brachiopods (e.g. Sartenaer 1972, Mottequin 2008), conodonts (e.g. Bouckaert et al. 1965, Dreesen 1978), corals (e.g. Poty 1999, Poty et al. 2006, Denayer et al. 2012), and the foraminifers (Conil et al. 1986, Poty et al. 2006).

The present paper is the first systematic study of bryozoans from the middle and uppermost Famennian of the 


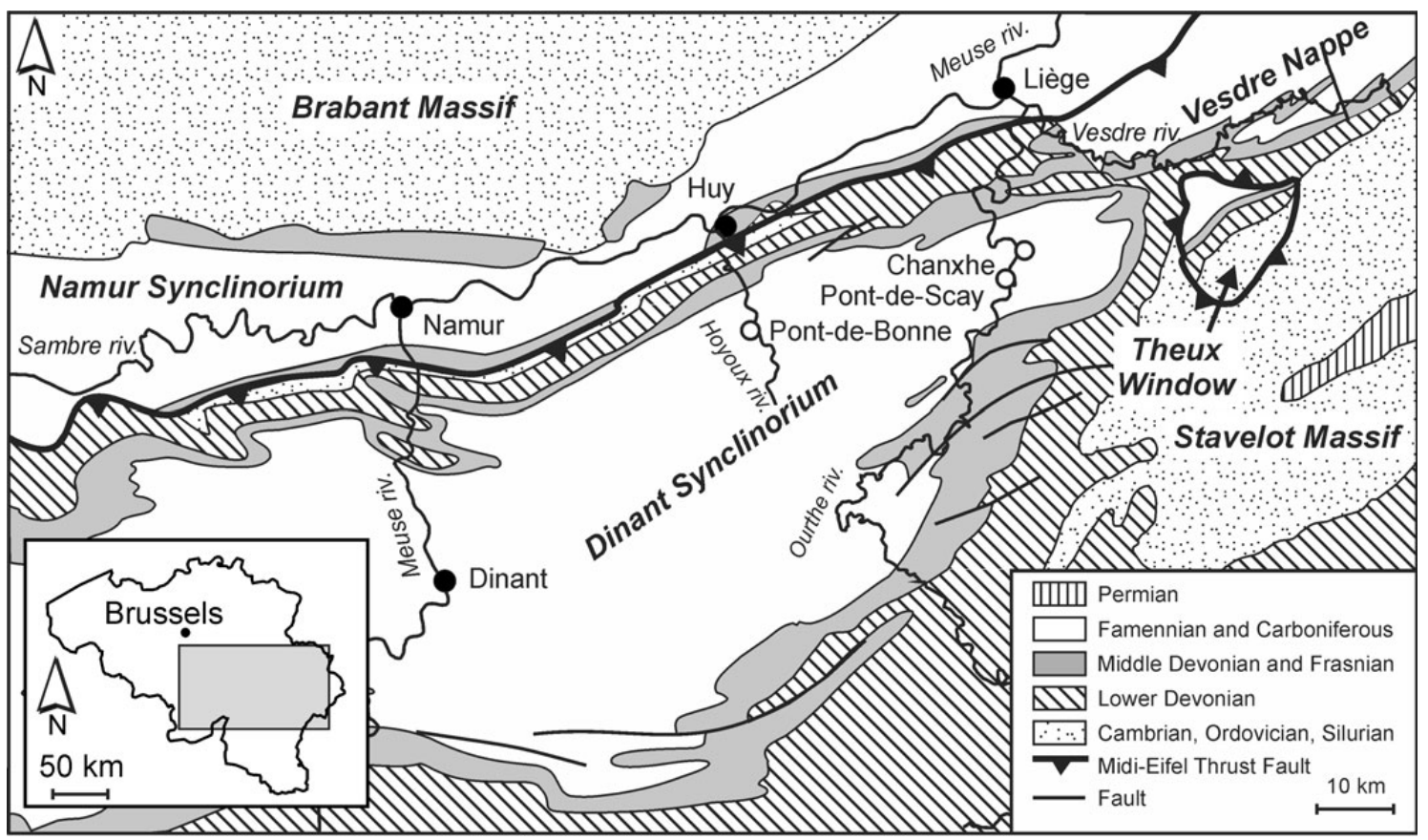

Figure 1. Location and schematic geological map of southern Belgium with indication of the sampled localities (modified from de Béthune 1954).

Dinant Synclinorium (southern Belgium). They are of interest for biodiversity studies and allow for comparisons with other Famennian bryozoan faunas from Eurasia.

\section{Material and methods}

The studied material comes from three localities situated in the northern (Pont-de-Bonne) and the eastern (Chanxhe and Pont-de-Scay) parts of the Dinant Synclinorium (Fig. 1). All the localities were sampled during the summer 2013 and 23 thin sections were prepared: four sections from Pont-de-Bonne (PDB), 13 sections from Pont-deScay (PDS), and six from Chanxhe (Ch). This material was complemented by the study in 2013 of the E. Poty collections of lithological and coral thin sections.

The investigated bryozoans were studied in thin sections using a transmitted light binocular microscope. Morphological character terminology is adopted from Anstey \& Perry (1970) for trepostomes, and Hageman (1993) for cryptostomes. All the studied material is housed at the Department of Palaeontology of the University of Liège (prefix: ULg).

\section{Geological setting}

The Dinant Synclinorium is a Variscan structural element, along with the "Namur Synclinorium" (see Belanger et al. 2012 for discussion about the this structural unit), the Vesdre area and the Theux Window, constituted the Na-
mur-Dinant Basin (Fig. 1), which developed along the southeastern margin of Laurussia during Devonian and Mississippian times. The Famennian is particularly well developed in the Dinant Synclinorium where it comprises a $600 \mathrm{~m}$-thick sequence, which is predominantly dominated by siliciclastic sediments with some carbonate levels (Thorez et al. 2006). The depositional setting approximately corresponds to a ramp with an accentuation of the marine influence and a southward deepening setting (Thorez et al. 2006). Therefore, the northern proximal facies, which frequently show a continental influence, are dominantly sandy, silty and shaly, whereas the southern distal facies are essentially shaly with some carbonate intercalations.

Bryozoans were recovered from three distinct lithostratigraphic units, namely the Souverain-Pré, Comblainau-Pont and Hastière formations (Fig. 2). The middle Famennian Souverain-Pré Formation comprises to thick layers (pluridecimetric to plurimetric) of nodular, bioclastic (crinoids, brachiopods, bryozoans) limestones with shaly to silty cement and intercalations of calcareous sandstones (e.g. Dreesen 1978, Bultynck \& Dejonghe 2002, Thorez et al. 2006). Locally, in the Vesdre area, red-stained carbonate mudmounds are developed and these make up to the Baelen Member (Dreesen et al. 1985, 2013). Material from the Souverain-Pré Formation has been collected in the Pont-de-Bonne section (N 50 27'03.38"; E $5^{\circ} 16^{\prime} 57.48^{\prime \prime}$ ) in the Hoyoux valley, which was previously described by Bouckaert et al. (1965) and Dreesen (1978). This lithostratigraphic unit reaches at least $10 \mathrm{~m}$ in thickness in this section (its top is not exposed) and is 


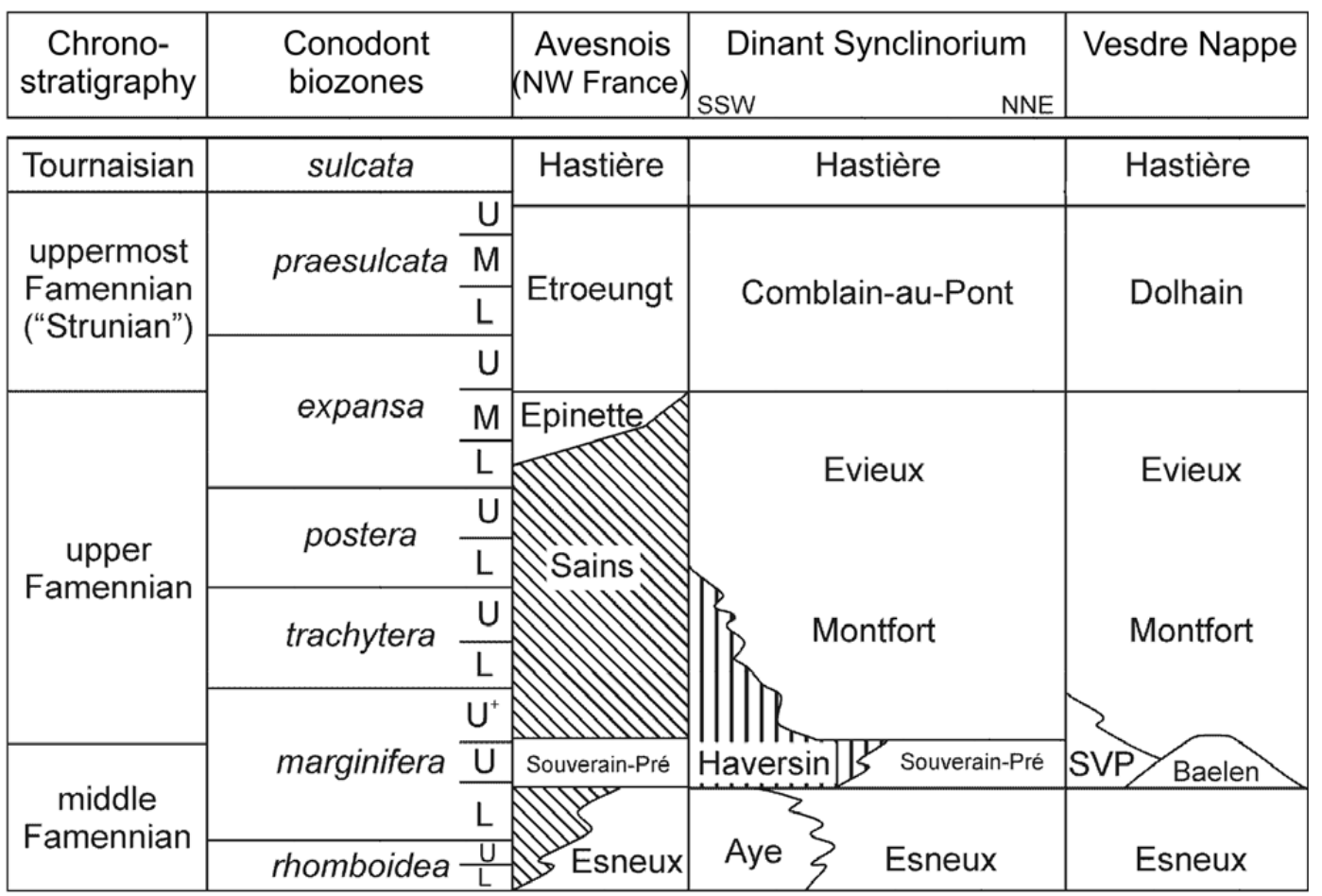

Figure 2. Partial lithostratigraphical scheme of the middle Famennian to the base of the Tournaisian in some tectonic units of southern Belgium (Dinant Synclinorium, Vesdre Nappe) and northern France (Avesnois) (modified from Thorez et al. 2006)

included in the Palmatolepis marginifera conodont Zone (Dreesen 1978).

The uppermost Famennian ("Strunian") Comblain-auPont Formation is composed of green shales and siltstones interbedded with argillaceous or calcareous, micaceous sandstones, and limestones. The latter are frequently crinoidal and become more abundant at the top of the formation (Bultynck \& Dejonghe 2002). The presence of stromatoporoid biostromes is characteristic of this unit. Bryozoans from the Comblain-au-Pont Formation come from the Chanxhe (Ch.) and Pont-de-Scay sections, both are situated in the Ourthe valley. The Chanxhe section ( N 50³0' 17.15"; E $5^{\circ} 35^{\prime} 47.31^{\prime \prime}$ ) has been described in great detail by several authors (e.g. Conil 1964, Maziane et al. 1999, Casier et al. 2005, Maziane-Serraj et al. 2007). We refer here to Conil (1964)'s bed numbers (e.g. Ch-127) that were used by subsequent workers. The Pont-de-Scay

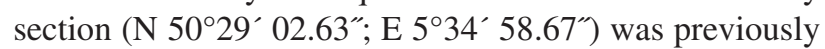
described by several authors for its Tournaisian and Viséan succession (e.g. Conil 1968, Groessens 1975, Poty et al. 2011). Figure 3 illustrates the contact between the Comblain-au-Pont and the Hastière Formation in this section.

The Hastière Formation is essentially calcareous with thin shaly intercalations (see Poty et al. 2002 for a complete description). The bottom part of the formation is of uppermost Famennian age and yields typical elements of a Devonian fauna, but they are generally reworked; the rest of the formation is of Hastarian age (basal Tournaisian). Only the bryo- zoans from the basal bed (No. 101) of the Hastière Formation exposed in the Pont-de-Scay (see above) section have been studied. According to Poty et al. (2011), who placed the base of the Hastière Formation at the first occurrence of a metre-thick limestone bed, the facies is unchanged between the limestones of the top of the Comblain-au-Pont and those of the base of the Hastière Formation, but the last uppermost Famennian faunas (Cryptophyllus, quasiendothyrids) are found in the first bed (bed No. 101) of the latter (Fig. 3).

\section{Systematic palaeontology}

Phylum Bryozoa Ehrenberg, 1831

Class Stenolaemata Borg, 1926

Order Trepostomida Ulrich, 1882

Suborder Amplexoporina Astrova, 1965

Family Dyscritellidae Dunaeva \& Morozova, 1967

\section{Genus Dyscritella Girty, 1911}

Type species. - Dyscritella robusta Girty, 1911. Mississippian (Lower Carboniferous); Arkansas, USA.

Diagnosis. - Dendroid and encrusting colony with abundant acanthostyles and exilazooecia. Autozooecia parallel to longitudinal direction of the colony in endozone; gradually bending outward in exozone. Diaphragms in autozooecia lacking or very rare; lacking in exilazooecia. 


\section{Bed no.}

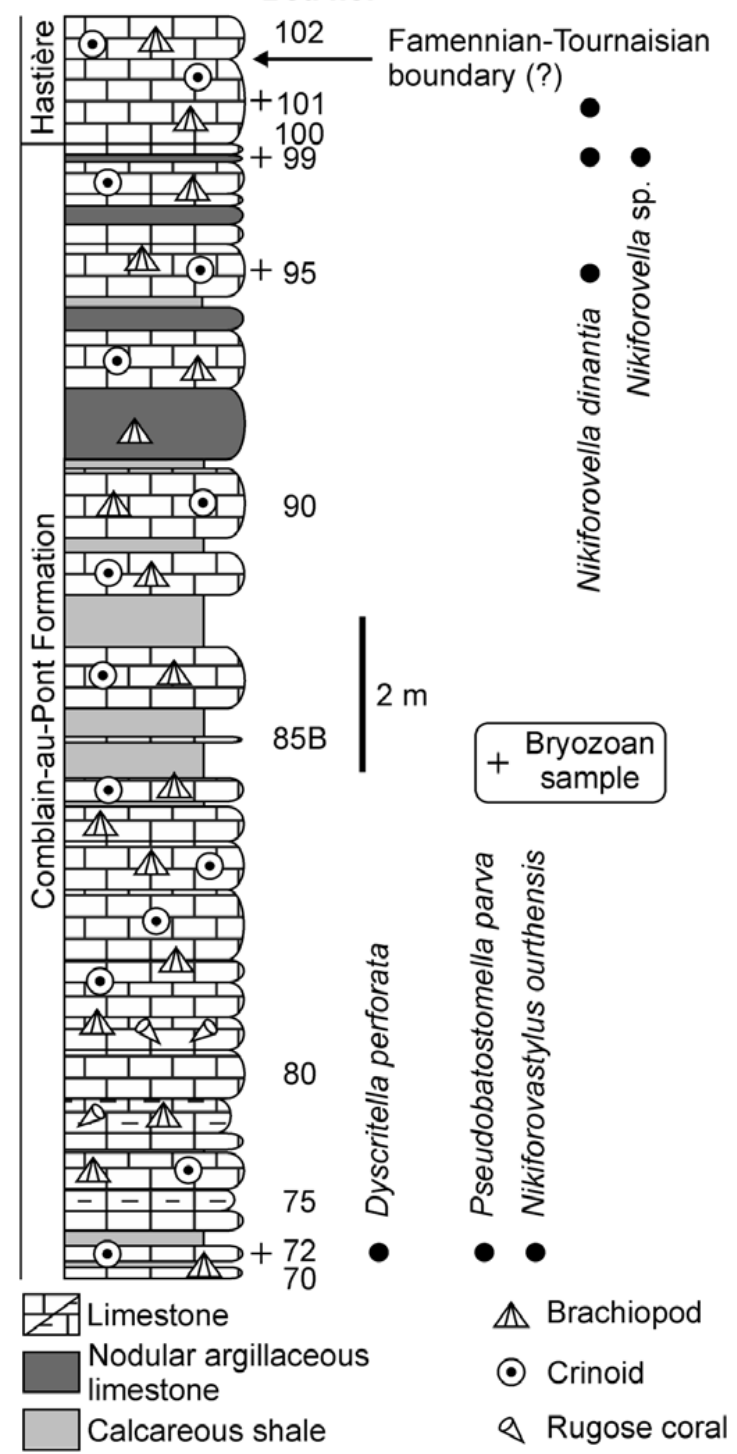

Figure 3. Schematic log of the upper part of the Comblain-au-Pont Formation and the base of the Hastière Formation in the Pont-de-Scay section (modified from unpublished data of R. Conil and M. Sautois).

Exilazooecia circular to angular in cross section and separated from the autozooecia and from each other by thick walls. Two sizes of acanthostyles may be present. Zooecial walls thin in endozone, rapidly thickening in the exozone (modified after Ernst \& Gorgij 2013).

Remarks. - Dyscritella Girty, 1911 generally lacks diaphragms which are commonly developed in the similar genus Dyscritellina Morozova in Dunaeva \& Morozova, 1967. Furthermore, Dyscritellina has extremely large acanthostyles, which are absent in Dyscritella.

Occurrence. - Devonian to Triassic; worldwide.

\section{Dyscritella perforata sp. nov. \\ Figure 4A-H, Table 1}

Type horizon and locality. - Upper Devonian, uppermost Famennian, Comblain-au-Pont Formation; Pont-de-Scay, Belgium.

Holotype. - ULg PDS-72a.

Paratypes. - ULg PDS-72 (2007), PDS-72d, e, f, h, j, k, l, m, ULg Ch-113a.

Etymology. - The species name refers to the presence of abundant exilazooecia (from Latin "perforata" - porous).

Diagnosis. - Encrusting colonies; autozooecial diaphragms rare to absent; exilazooecia abundant, 5-11 surrounding each autozooecial aperture, 0.015-0.07 mm wide; acanthostyles abundant $0.015-0.045 \mathrm{~mm}$ in diameter, 2-6 surrounding each autozooecial aperture; maculae not observed.

Description. - Colonies encrusting often cylindrical ephemeral substrates, therefore, appearing tubulose. Encrusting sheets $0.20-0.45 \mathrm{~mm}$ thick. Autozooecia growing from 0.003-0.006 $\mathrm{mm}$ thick epitheca, for the short distance parallel to the substrate, then bending sharply to the colony surface. Autozooecial diaphragms rare to absent, thin. Autozooecial apertures rounded to slightly polygonal. Exilazooecia abundant, 0.015-0.07 mm wide, 5-11 surrounding each autozooecial aperture, with polygonal apertures. Acanthostyles abundant $0.015-0.045 \mathrm{~mm}$ in diameter, locally indenting autozooecial apertures, having distinct hyaline cores and wide laminated sheaths, 2-6 surrounding each autozooecial aperture. Autozooecial walls laminated, 0.005-0.010 $\mathrm{mm}$ thick in endozones; laminated, merged without zooecial boundaries, 0.02-0.05 $\mathrm{mm}$ thick in exozone. Maculae not observed.

Remarks. - Dyscritella perforata sp. nov. differs from D. clara (Trizna 1958) from the Tournaisian of the Kuznetsk

Figure 4. A-H - Dyscritella perforata sp. nov. • A, B - longitudinal section, holotype ULg PDS-72a. • C - tangential section, holotype ULg PDS-72a. - D - tangential section, paratype ULg PDS-72d. • E-G - longitudinal section, paratype ULg PDS-72h. $\bullet$ H - tangential section, paratype ULg PDS-72f. - I-K - Pseudobatostomella parva sp. nov. • I - oblique section of the branch, paratype ULg PDS-72g. $\bullet \mathrm{J}-$ branch transverse section, paratype ULg PDS-72g. $\bullet \mathrm{K}$ - tangential section, holotype ULg PDS-72c. 

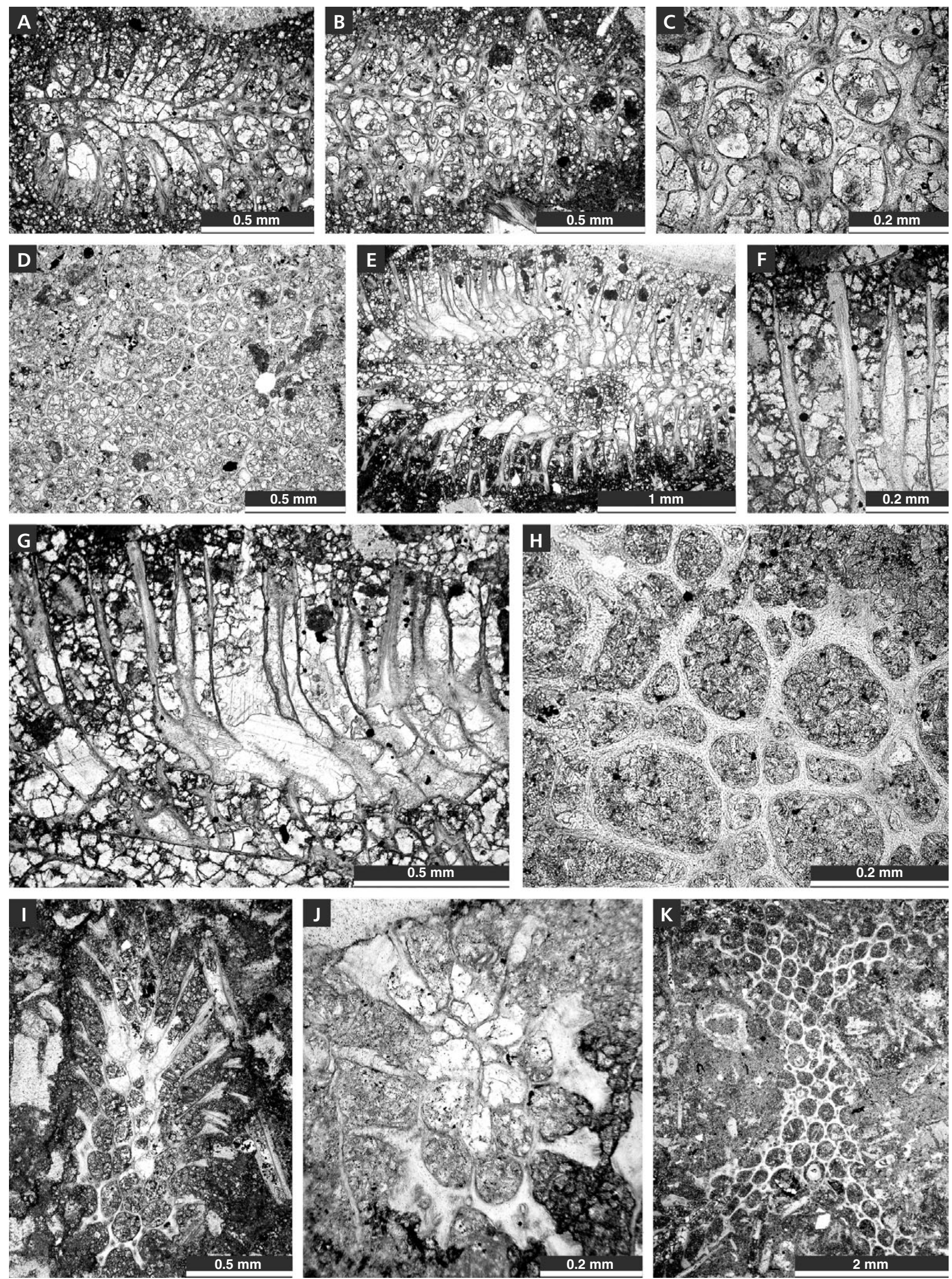
Table 1. Measurements of Dyscritella perforata sp. nov. Abbreviations: $\mathrm{F}=$ number of measured fragments; $\mathrm{N}=$ number of measurements; $\mathrm{X}=$ mean $\mathrm{SD}=$ standard deviation $; \mathrm{CV}=$ coefficient of variation; $\mathrm{MIN}=$ minimal value MAX $=$ maximal value.

\begin{tabular}{|c|c|c|c|c|c|c|c|}
\hline & $\mathrm{F}$ & $\mathrm{N}$ & $\mathrm{X}$ & SD & $\mathrm{CV}$ & MIN & MAX \\
\hline & 9 & 10 & 0.45 & 0.173 & 38.82 & 0.20 & 0.75 \\
\hline $\begin{array}{l}\text { Autozooecial aperture } \\
\text { width, mm }\end{array}$ & 12 & 50 & 0.14 & 0.016 & 12.00 & 0.10 & 0.17 \\
\hline $\begin{array}{l}\text { Autozooecial aperture } \\
\text { spacing, } \mathrm{mm}\end{array}$ & 12 & 50 & 0.20 & 0.032 & 15.78 & 0.14 & 0.28 \\
\hline & 12 & 54 & 0.041 & 0.012 & 28.93 & 0.015 & 0.070 \\
\hline Acanthostyle diameter, mm & 12 & 45 & 0.031 & 0.009 & 27.57 & 0.015 & 0.045 \\
\hline Exilazooecia per aperture & 12 & 30 & 7.6 & 1.632 & 21.47 & 5.0 & 11.0 \\
\hline Acanthostyles per aperture & 12 & 30 & 2.7 & 0.884 & 33.15 & 2.0 & 6.0 \\
\hline $\begin{array}{l}\text { Exozonal wall thickness, } \\
\mathrm{mm}\end{array}$ & 12 & 10 & 0.03 & 0.009 & 34.88 & 0.02 & 0.05 \\
\hline
\end{tabular}

Basin in colony form (encrusting $v s$ branched ramose), possessing more abundant exilazooecia and in smaller autozooecial apertures $(0.10-0.17 \mathrm{~mm}$ vs $0.16-0.24 \mathrm{~mm}$ in D. clara). Dyscritella perforata sp. nov. differs from $D$. multifida Lee, 1912 from the Tournaisian of Ireland in colony form (encrusting $v s$ branched ramose). No measurements are given for the latter species, except of arrangement of 40 apertures per $10 \mathrm{~mm}$ (Lee 1912, p. 180). This value produces an average autozooecial aperture spacing of $0.25 \mathrm{~mm}$, which is larger than in $D$. perforata $(0.20 \mathrm{~mm}$ in average).

Occurrence. - Pont-de-Scay, Chanxhe, Belgium; uppermost Famennian.

\section{Genus Pseudobatostomella Morozova, 1960}

Type species. - Batostomella spinulosa Ulrich, 1890. Mississippian (Lower Carboniferous); Kentucky, U.S.A.

Diagnosis. - Ramose cylindrical colonies. Autozooecial apertures irregularly rounded or oval, arranged in more or less regular diagonal rows. Diaphragms complete, thin, most abundant in the transition between endozones and exozones. Exilazooecia usually rare, short. Acanthostyles small, abundant, regularly sized. Walls irregularly thickened.

Remarks. - The genus Pseudobatostomella Morozova, 1960 differs from the genus Dyscritella Girty, 1911 in its autozooecial budding pattern, the presence of diaphragms and regularly sized acanthostyles.
Occurrence. - Upper Devonian to Upper Permian; worldwide.

Pseudobatostomella parva sp. nov. Figures 4I-K, 5A-E, Table 2

Type horizon and locality. - Upper Devonian, uppermost Famennian, Comblain-au-Pont Formation; Pont-de-Scay, Belgium.

Holotype. - ULg PDS-72c.

Paratypes. - ULg PDS-72b, h, m.

Etymology. - The species name refers to the small size of this species (from Latin "parva" - small).

Diagnosis. - Thin branched colonies; autozooecial apertures rounded; autozooecial diaphragms rare; 1-5 exilazooecia surrounding each autozooecial aperture; 3-8 acanthostyles surrounding each autozooecial aperture; maculae not observed.

Description. - Branched colonies, $0.40-0.80 \mathrm{~mm}$ in diameter, with $0.13-0.20 \mathrm{~mm}$ wide exozones and $0.10-0.40 \mathrm{~mm}$ wide exozones. Autozooecia long in endozones, bending at low angles in exozones. Autozooecial apertures rounded. Autozooecial diaphragms rare. Autozooecial walls laminated, 0.005-0.075 mm thick in endozone; merged without visible zooecial boundaries, $0.025-0.040 \mathrm{~mm}$ thick in exozone. Exilazooecia $0.018-0.045 \mathrm{~mm}$ wide, short, common to abundant, 1-5 surrounding each autozooecial aperture. Acanthostyles abundant, $0.015-0.040 \mathrm{~mm}$ in diameter, with narrow hyaline cores and wide laminated sheaths, 3-8 surrounding each autozooecial aperture. Maculae not observed.

Remarks. - Pseudobatostomella parva sp. nov. differs from P. amazagensis Modzalevskaya, 1960 from the Famennian of Transbaikalia in having narrower branches (0.40-0.80 mm vs $2.0 \mathrm{~mm}$ in P. amazagensis) and larger autozooecial apertures $(0.11-0.19 \mathrm{~mm}$ vs $0.10-0.12 \mathrm{~mm}$ in P. amazagensis). Pseudobatostomella parva sp. nov. differs from $P$. abrupta (Ulrich, 1890) from the Mississippian of the USA in its narrower branches $(0.40-0.80 \mathrm{~mm} \mathrm{vs}$ 2.0-3.0 mm in P. abrupta).

Occurrence. - Pont-de-Scay, Belgium; uppermost Famennian.

Figure 5. A-E - Pseudobatostomella parva sp. nov. $・$ A, B - tangential section, holotype ULg PDS-72c. $\bullet$ C-E - longitudinal section, holotype ULg PDS-72c. • F-H - Trepostomata sp. indet. • F, G - branch transverse section, ULg PDB-5-21b. • H - branch transverse section, ULg PDB-5-21a. 

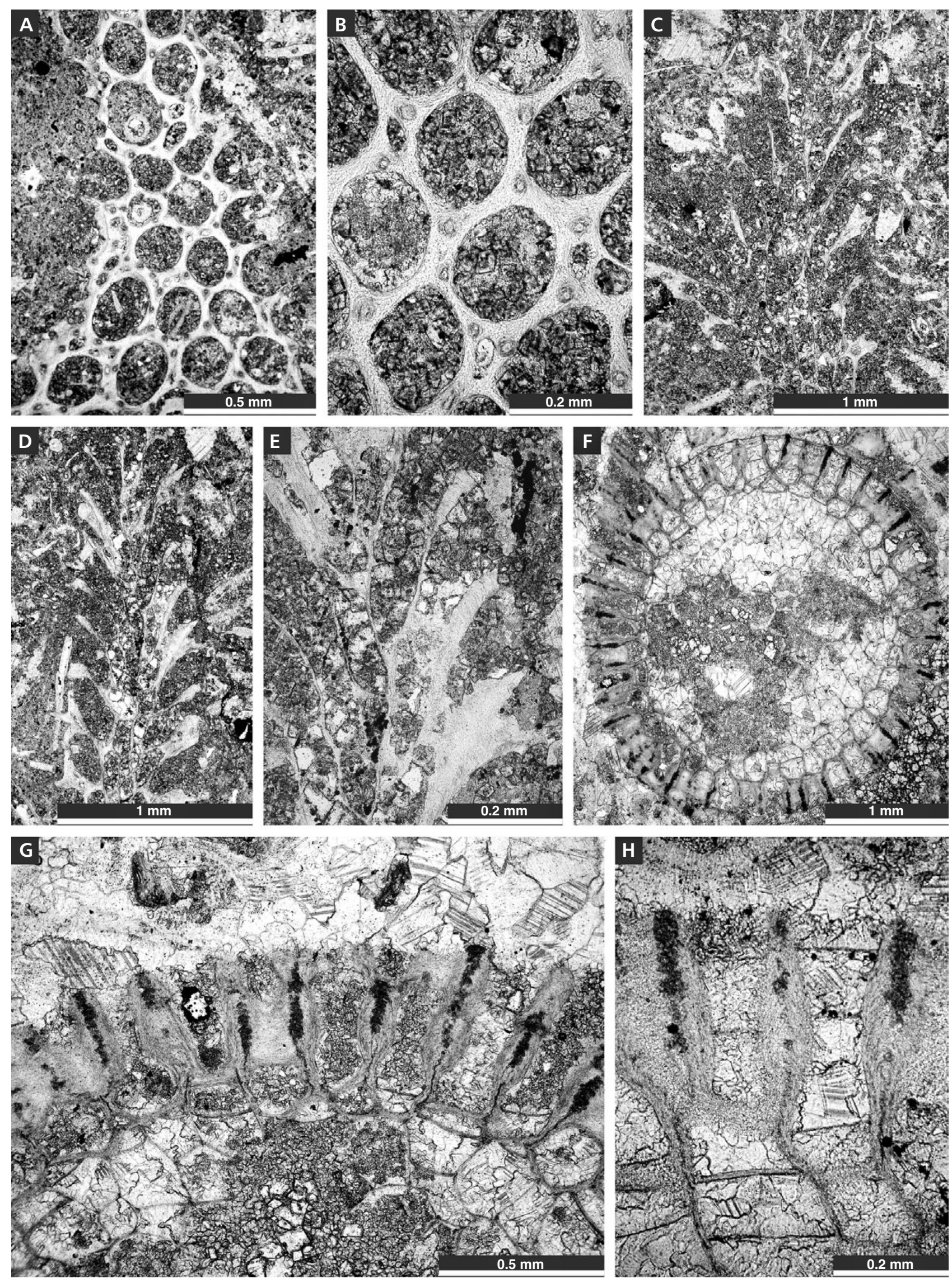
Table 2. Measurements of Pseudobatostomella parva sp. nov. Abbreviations as in Table 1.

\begin{tabular}{lccccccc}
\hline & $\mathrm{F}$ & $\mathrm{N}$ & $\mathrm{X}$ & $\mathrm{SD}$ & $\mathrm{CV}$ & MIN & MAX \\
\hline Branch width, mm & 5 & 5 & 0.60 & 0.146 & 24.30 & 0.40 & 0.80 \\
Exozone width, mm & 5 & 5 & 0.16 & 0.026 & 16.72 & 0.13 & 0.20 \\
Endozone width, mm & 5 & 5 & 0.29 & 0.114 & 39.54 & 0.10 & 0.40 \\
$\begin{array}{l}\text { Autozooecial aperture width, } \\
\text { mm }\end{array}$ & 6 & 25 & 0.14 & 0.020 & 14.20 & 0.11 & 0.19 \\
$\begin{array}{l}\text { Autozooecial aperture spacing, } \\
\text { mm }\end{array}$ & 6 & 25 & 0.20 & 0.029 & 14.70 & 0.16 & 0.26 \\
Acanthostyle diameter, mm & 6 & 30 & 0.028 & 0.006 & 21.86 & 0.015 & 0.040 \\
Acanthostyles per aperture & 6 & 25 & 5.04 & 1.136 & 22.54 & 3.0 & 8.0 \\
Exilazooecia width, mm & 6 & 30 & 0.028 & 0.008 & 28.41 & 0.018 & 0.045 \\
Exilazooecia per aperture & 6 & 21 & 2.81 & 1.030 & 36.68 & 1.0 & 5.0 \\
Exozone wall thickness, mm & 5 & 5 & 0.03 & 0.006 & 19.08 & 0.025 & 0.040 \\
\hline
\end{tabular}

Family uncertain

Trepostomata sp. indet. Figures 5F-H, 6A-C

Material. - ULg PDB 5-21a-d.

Description. - Branched colonies, 2.38-3.25 $\mathrm{mm}$ in diameter, with $0.30-0.45 \mathrm{~mm}$ wide exozones and $1.48-2.55 \mathrm{~mm}$ wide exozones. Secondary overgrowth occurring, $0.40-0.65 \mathrm{~mm}$ thick. Autozooecia long in endozones, bending abruptly in exozones. Autozooecial apertures rounded-polygonal, $0.11-0.15 \mathrm{~mm}$ in diameter. Autozooecial diaphragms common to abundant in the transition between endozone and exozone, straight, thin to moderately thick. Autozooecial walls laminated, 0.025-0.075 mm thick in endozone; with serrated dark zooecial boundaries at the base of exozone and merged in the outer part of exozone, $0.03-0.11 \mathrm{~mm}$ thick in exozone. Heterostyles abundant, consisting of dark granulated material, irregularly shaped, restricted to exozone and not protruding above the colony surface, $0.03-0.04 \mathrm{~mm}$ in diameter. Maculae not observed.

Remarks. - The present material displays a type of heterostyles, which is hitherto unknown in Palaeozoic bryozoans. They bear slight resemblance to cryptostyles of the cryptostome genus Cryptostyloecia Ernst, Königshof \& Schäfer, 2009, from the Middle Devonian of Western Sahara. However, those styles have smooth outlines in longitudinal section, whereas heterostyles in the present material are irregularly shaped (Fig. 5G, H). The usual type of styles in Palaeozoic bryozoans are acanthostyles, which represent cylindrical bodies with a distinct hyaline core jacketed by laminated sheath (Armstrong 1970; Blake 1973, 1983; see Dyscritella perforata sp. nov., Fig 4C, H, and Pseudobatostomella parva sp. nov., Fig. 5A, B). Acanthostyles usually protrude above the colony surface, often implying a protective function. Alternative opinion regards acanthostyles as supporting structures of the surficial tissue (Tavener-Smith 1975). Such structures are unknown in living bryozoans, therefore we do not know their function. Some modern bryozoans can produce spines as a reaction to the presence of predators (nudibranchs) (e.g., Harvell 1984, 1992). The truth may be that the function of acanthostyles depends on their morphology and position in the colony (e.g., Blake 1983). Some trepostome genera have heterostyles, which consist of granular material and have irregular shape. The most similar genus Nikiforopora Dunaeva, 1964 from the Mississippian of Ukraine and Russia, has normal acanthostyles and smaller heterostyles without cores, which resemble the styles of the present material. However, $\mathrm{Ni}$ kiforopora possesses hemiphragms, which are absent in the present species. Besides the styles, the present species shows characteristic morphology of autozooecial walls (serrated in the basal exozone and merged in the outer exozone), which makes it similar to amplexoporine trepostomes, especially stenoporids.

Occurrence. - Pont-de-Bonne, Belgium; Upper Devonian, middle Famennian, base of the Souverain-Pré Formation.

Order Cryptostomida Vine, 1884

Suborder Rhabdomesina Astrova \& Morozova, 1956

Family Rhomboporidae Simpson, 1895

\section{Rhomboporidae sp. indet.}

Figure 6D-I, Table 3

Material. - ULg Ch-127a-b, Ch-150c, PDS-72a, b, h, m.

Description. - Branched colonies, 0.54-0.80 $\mathrm{mm}$ in diameter, with $0.16-0.25 \mathrm{~mm}$ wide exozones and 0.22 to $0.35 \mathrm{~mm}$ wide exozones. Autozooecia growing from the distinct median axis, long in endozones, bending at low angles in exozones. Autozooecial apertures rounded. Autozooecial diaphragms rare. Autozooecial walls laminated, 0.005 to $0.0075 \mathrm{~mm}$ thick in endozone; laminated,

Figure 6. A-C - Trepostomata sp. indet., ULg PDB-5-21d. $\bullet$ A - branch longitudinal section. $\bullet$ B - longitudinal section of exozone. $\bullet$ C - oblique tangential section. $\bullet$ D-I - Rhomboporidae sp. indet. $\bullet$ D, E - longitudinal section, ULg PDS-72a. $\bullet$ F - tangential section, ULg PDS-72a. $\bullet$ G, H - longitudinal section, ULg Ch-127. • I - branch oblique section, ULg Ch-127. 

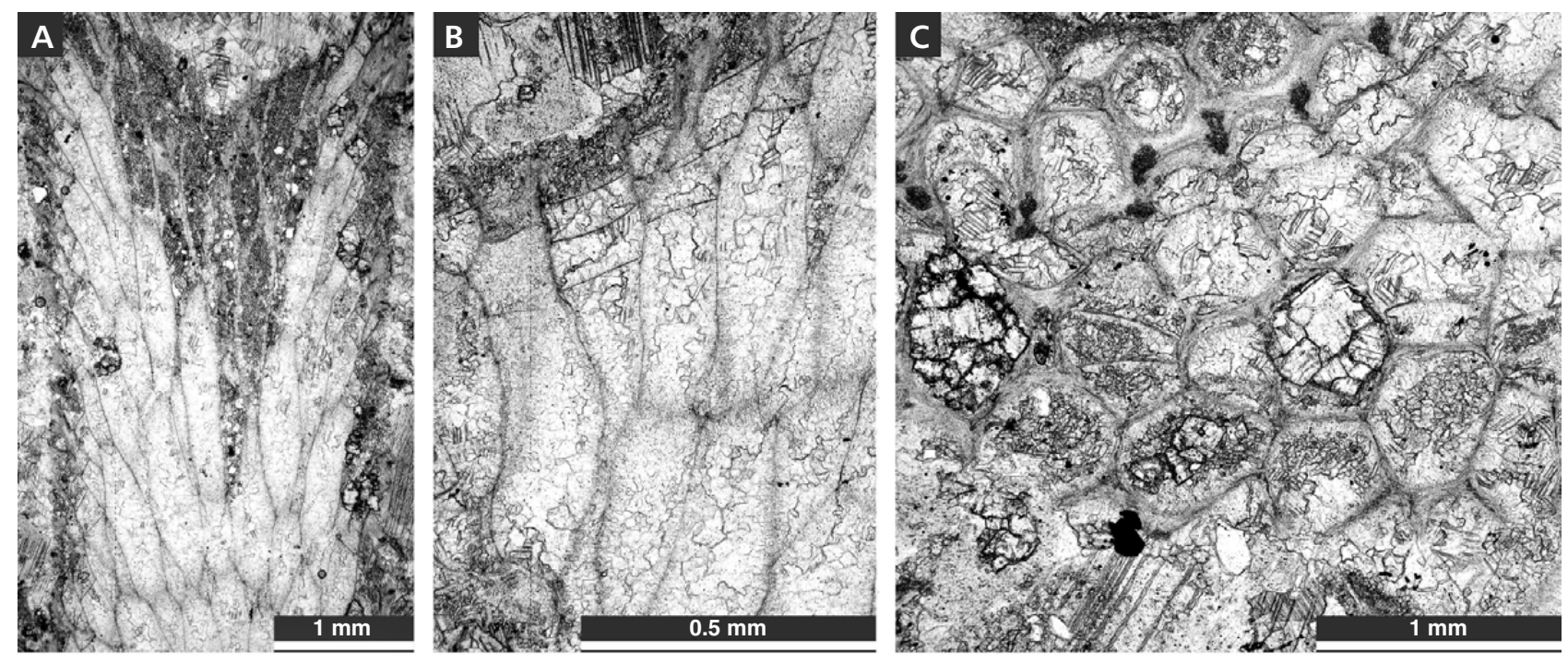
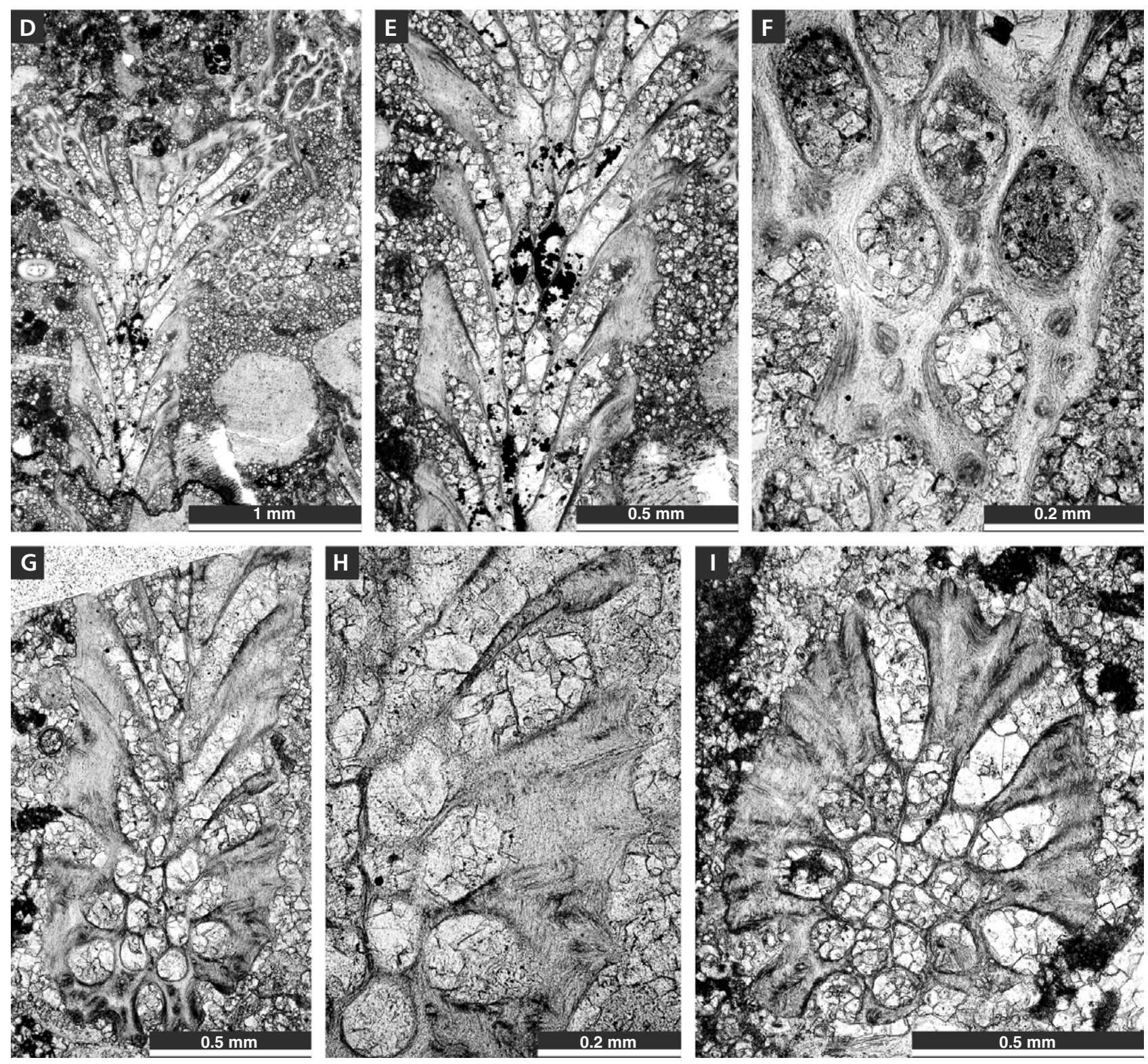
Table 3. Measurements of Rhomboporidae sp. indet. Abbreviations as in Table 1.

\begin{tabular}{|c|c|c|c|c|c|c|c|}
\hline & $\mathrm{F}$ & $\mathrm{N}$ & $\mathrm{X}$ & SD & $\mathrm{CV}$ & MIN & MAX \\
\hline Branch width, mm & 6 & 6 & 0.69 & 0.089 & 12.82 & 0.54 & 0.80 \\
\hline Exozone width, mm & 6 & 6 & 0.20 & 0.030 & 15.10 & 0.16 & 0.25 \\
\hline Endozone width, mm & 6 & 6 & 0.30 & 0.044 & 14.87 & 0.22 & 0.35 \\
\hline $\begin{array}{l}\text { Autozooecial aperture width, } \\
\mathrm{mm}\end{array}$ & 7 & 20 & 0.09 & 0.011 & 12.94 & 0.06 & 0.10 \\
\hline $\begin{array}{l}\text { Autozooecial aperture } \\
\text { spacing, } \mathrm{mm}\end{array}$ & 7 & 17 & 0.19 & 0.021 & 10.85 & 0.15 & 0.23 \\
\hline Acanthostyle diameter, mm & 7 & 25 & 0.03 & 0.007 & 18.83 & 0.02 & 0.05 \\
\hline Exozonal wall thickness, mm & 5 & 5 & 0.047 & 0.011 & 23.04 & 0.035 & 0.063 \\
\hline
\end{tabular}

merged without visible zooecial boundaries, 0.035 to $0.063 \mathrm{~mm}$ thick in exozone. Acanthostyles common to abundant, 0.02 to $0.05 \mathrm{~mm}$ in diameter. Heterozooecia absent. Maculae not observed.

Remarks. - The present material resembles Klaucena (Spira) Trizna, 1958 from the Tournaisian of the Kuznetsk Basin in Russia. It differs in more abundant acanthostyles [4-8 vs 1-2 in Klaucena (Spira)] and forming median axis only [vs median axis and mesotheca in Klaucena (Spira)].

Occurrence. - Pont-de-Scay, Chanxhe, Belgium; Upper Devonian, uppermost Famennian, Comblain-au-Pont Formation.

Family Nikiforovellidae Goryunova, 1975

Genus Nikiforovastylus gen. nov.

Type species. - Nikiforovastylus ourthensis sp. nov., by original designation. Upper Devonian, uppermost Famennian; Pont-de-Scay, Belgium.

Etymology. - The genus is named in honour of Alexandra I. Nikiforova (1894-1939), Russian bryozoologist in acknowledgement of her contribution to the study of Palaeozoic bryozoans.

Diagnosis. - Branched colonies. Autozooecia diverging at low angles from distinct median axis, polygonal at their bases in endozone, with rounded apertures at colony surface. Hemisepta absent, diaphragms rare. Autozooecial walls laminated, with dark zooecial boundaries. Few meta- zooecia and aktinotostyles between longitudinally successive autozooecial apertures. Longitudinal ridges absent.

Remarks. - Nikiforovastylus gen. nov. differs from Nikiforovella Nekhoroshev, 1948 in possessing of aktinotostyles rather than acanthostyles as in the latter genus. Nikiforovastylus differs from Pinegopora Shishova, 1965 in this regular arrangement of metazooecia and aktinotostyles and in the more regular shape of autozooecia.

Occurrence. - Upper Devonian, uppermost Famennian, Comblain-au-Pont Formation; Pont-de-Scay, Belgium.

\section{Nikiforovastylus ourthensis gen. et sp. nov.}

Figure 7A-I, Table 4

Type horizon and locality. - Upper Devonian, uppermost Famennian, Comblain-au-Pont Formation; Pont-de-Scay, Belgium.

Holotype. - ULg PDS-72i.

Paratypes. - ULg PDS-72b, g, k.

Etymology. - The species name refers to the river Ourthe, in the vicinity of the type locality Pont-de-Scay.

Diagnosis. - As for genus.

Description. - Branched colonies, 0.75-0.96 $\mathrm{mm}$ in diameter, with $0.20-0.28 \mathrm{~mm}$ wide exozones and $0.35-0.47 \mathrm{~mm}$ wide endozones. Autozooecia growing in spiral pattern from the median axis, rhombic in the transverse section of endozone, abruptly bending in exozone. Autozooecial apertures oval to circular, arranged in regular diagonal rows. Autozooecial diaphragms absent. Metazooecia originating at the base of exozone, 1-2 arranged between longitudinally successive autozooecial apertures, 0.013 to $0.045 \mathrm{~mm}$ wide. Aktinotostyles $0.02-0.07 \mathrm{~mm}$ in diameter, 1-2 arranged between longitudinally successive autozooecial apertures, having distinct hyaline cores and laminated sheaths. Autozooecial walls granular, 0.005-0.010 mm thick in endozone; finely laminated, without visible zooecial boundaries in exozone.

Remarks. - As for genus.

Occurrence. - As for genus.

Figure 7. Nikiforovastylus ourthensis sp. nov. • A-D - longitudinal sections, holotype ULg PDS-72i. • E-G - tangential section, holotype ULg PDS-72i. • H-I - branch oblique section, paratype ULg PDS-72b. 

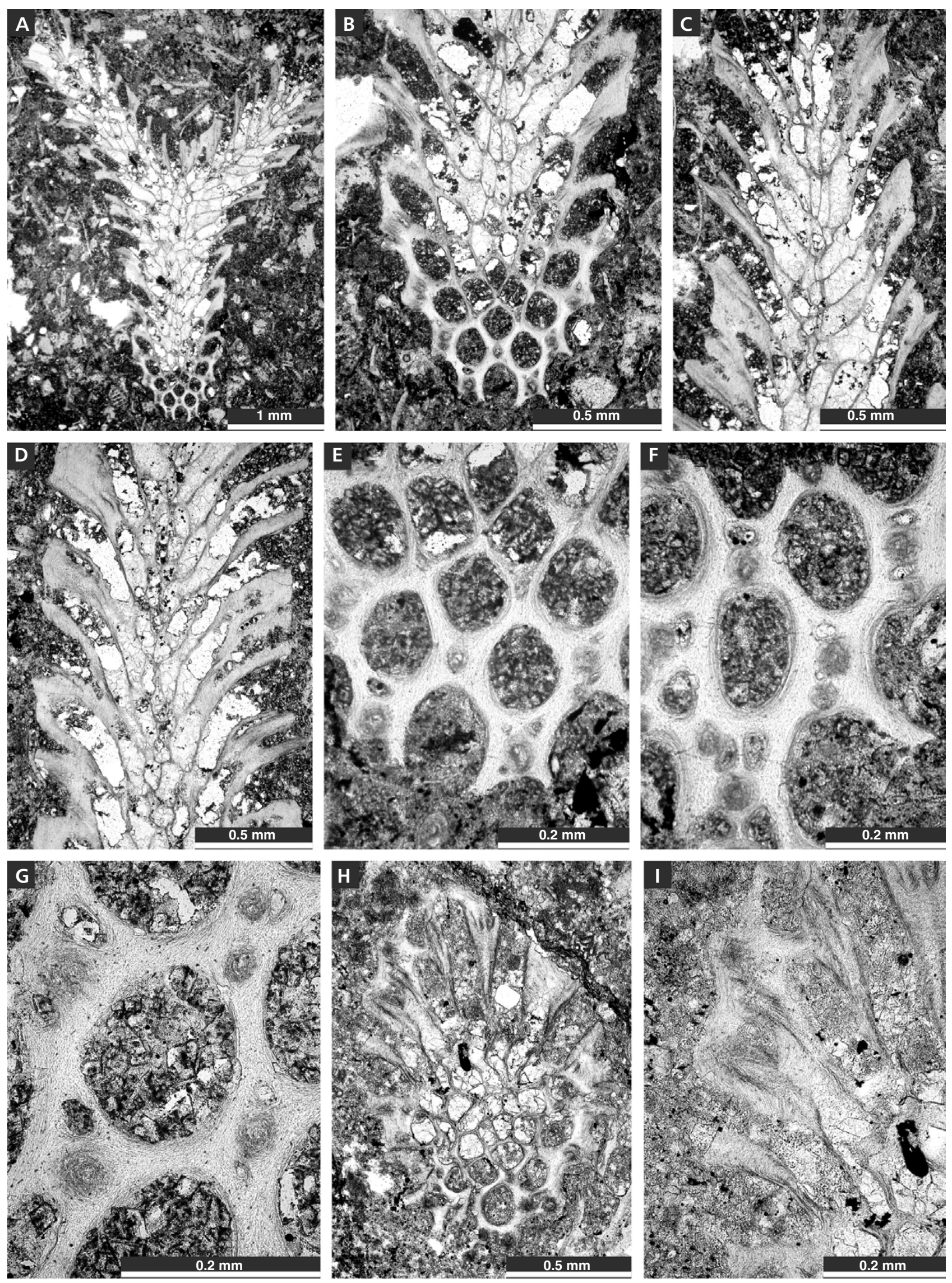
Table 4. Measurements of Nikiforovastylus ourthensis gen. et sp. nov. Abbreviations as in Table 1.

\begin{tabular}{|c|c|c|c|c|c|c|c|}
\hline & F & $\mathrm{N}$ & $\mathrm{X}$ & SD & $\mathrm{CV}$ & MIN & MAX \\
\hline Branch width, mm & 4 & 4 & 0.88 & 0.098 & 11.22 & 0.75 & 0.96 \\
\hline Exozone width, mm & 4 & 4 & 0.24 & 0.033 & 13.61 & 0.20 & 0.28 \\
\hline Endozone width, mm & 4 & 4 & 0.40 & 0.053 & 13.21 & 0.35 & 0.47 \\
\hline $\begin{array}{l}\text { Autozooecial aperture width, } \\
\text { mm }\end{array}$ & 4 & 25 & 0.10 & 0.020 & 19.41 & 0.07 & 0.13 \\
\hline $\begin{array}{l}\text { Autozooecial aperture spacing } \\
\text { along branch, mm }\end{array}$ & 4 & 21 & 0.34 & 0.030 & 8.66 & 0.27 & 0.39 \\
\hline $\begin{array}{l}\text { Autozooecial aperture spacing } \\
\text { diagonally, mm }\end{array}$ & 4 & 21 & 0.20 & 0.015 & 7.51 & 0.18 & 0.23 \\
\hline Aktinotostyle diameter, $\mathrm{mm}$ & 4 & 25 & 0.04 & 0.012 & 26.17 & 0.02 & 0.07 \\
\hline Metazooecia width, mm & 4 & 25 & 0.027 & 0.009 & 34.09 & 0.013 & 0.045 \\
\hline Acanthostyles per aperture & 4 & 20 & 1.5 & 0.513 & 34.20 & 1.0 & 2.0 \\
\hline Metazooecia per aperture & 4 & 20 & 1.6 & 0.503 & 31.41 & 1.0 & 2.0 \\
\hline
\end{tabular}

\section{Genus Nikiforovella Nekhoroshev, 1948}

Type species. - Nikiforovella alternata Nekhoroshev, 1948, by original designation. Mississippian (Lower Carboniferous); Altai, Russia.

Diagnosis. - Branched colonies. Autozooecia diverging at low angles from distinct median axis. Hemisepta absent, diaphragms rare. Autozooecial walls laminated, with dark zooecial boundaries. Metazooecia few between longitudinally successive autozooecial apertures; acanthostyles common to abundant. Longitudinal ridges absent.

Remarks. - Nikiforovella Nekhoroshev, 1948 is similar to Streblotrypella Nikiforova, 1948, but differs from it mainly in the shape of autozooecia, which bend at higher angles in exozone, and in the absence of longitudinal ridges. Moreover, styles can be absent in Streblotrypella.

Occurrence. - Devonian to Permian; worldwide.

\section{Nikiforovella dinantia sp. nov.}

Figure 8A-E, Table 5

Type horizon and locality. - Upper Devonian, uppermost Famennian, Comblain-au-Pont Formation; Pont-de-Scay, Belgium.

Holotype. - ULg PDS 95 (19.5-25).
Paratypes. - ULg PDS 99 (base), ULg PDS 95 (30.5-35), ULg PDS 101 (6-10), ULg PDS 99 (45.5-49).

Etymology. - The species is named after the Dinantian synclinorium, in which this species was found.

Diagnosis. - Branched colonies; autozooecial apertures oval to circular, arranged in regular diagonal rows; autozooecial diaphragms absent; 1-2 metazooecia and one acanthostyle arranged between longitudinally successive autozooecial apertures.

Description. - Branched colonies, 0.90-1.26 mm in diameter, with $0.23-0.36 \mathrm{~mm}$ wide exozones and $0.42-0.54 \mathrm{~mm}$ wide endozones. Autozooecia growing in spiral pattern from the median axis, rhombic in the transverse section of endozone, abruptly bending in exozone. Autozooecial apertures oval to circular, arranged in regular diagonal rows. Autozooecial diaphragms absent. Metazooecia 0.02-0.04 mm wide, originating at the base of exozone, 1-2 arranged between longitudinally successive autozooecial apertures. Single acanthostyle situated between longitudinally successive autozooecial apertures, having distinct hyaline cores and laminated sheaths, $0.025-0.050 \mathrm{~mm}$ in diameter. Autozooecial walls granular, $0.003-0.005 \mathrm{~mm}$ thick in endozone; finely laminated, without visible zooecial boundaries, $0.025-0.035 \mathrm{~mm}$ thick in exozone.

Remarks. - Nikiforovella dinantia sp. nov. differs from N. nitida Troizkaya, 1979 from the Famennian of Central Kazakhstan in possessing thicker branches (0.90-1.26 mm vs $0.60-0.65 \mathrm{~mm}$ in $N$. nitida). Furthermore, autozooecial apertures are spaced in Nikiforovella dinantia sp. nov. less closely than in Nikiforovella nitida (average aperture spacing along the branch $0.27 \mathrm{~mm} v s 0.22 \mathrm{~mm}$ in $N$. nitida). The new species differs from $N$. gracilis Ernst \& Herbig, 2010 in that it has fewer metazooecia and acanthostyles (1-2 vs 1-5 metazooecia between apertures in $N$. gracilis, and one vs 1-3 acanthostyles between apertures in N. gracilis).

Occurrence. - Pont-de-Scay, Belgium; uppermost Famennian, Comblain-au-Pont Formation.

\section{Nikiforovella sp.}

Figure 8F-I, Table 6

Material. - ULg PDS-72c, ULg PDS 99 (base) (two tangential sections of two colonies).

Figure 8. A-E - Nikiforovella dinantia sp. nov. $\bullet$ A, B - longitudinal section, holotype ULg PDS-95 (19,5-25). $\bullet$ - branch oblique section, paratype ULg PDS-99 (45.5-49). • D, E - longitudinal section, holotype ULg PDS-95 (19.5-25). • F-I - Nikiforovella sp. • F - tangential section, ULg PDS-72c. - G-H - tangential section, ULg PDS-99. • I - longitudinal section, PDS-72c. 

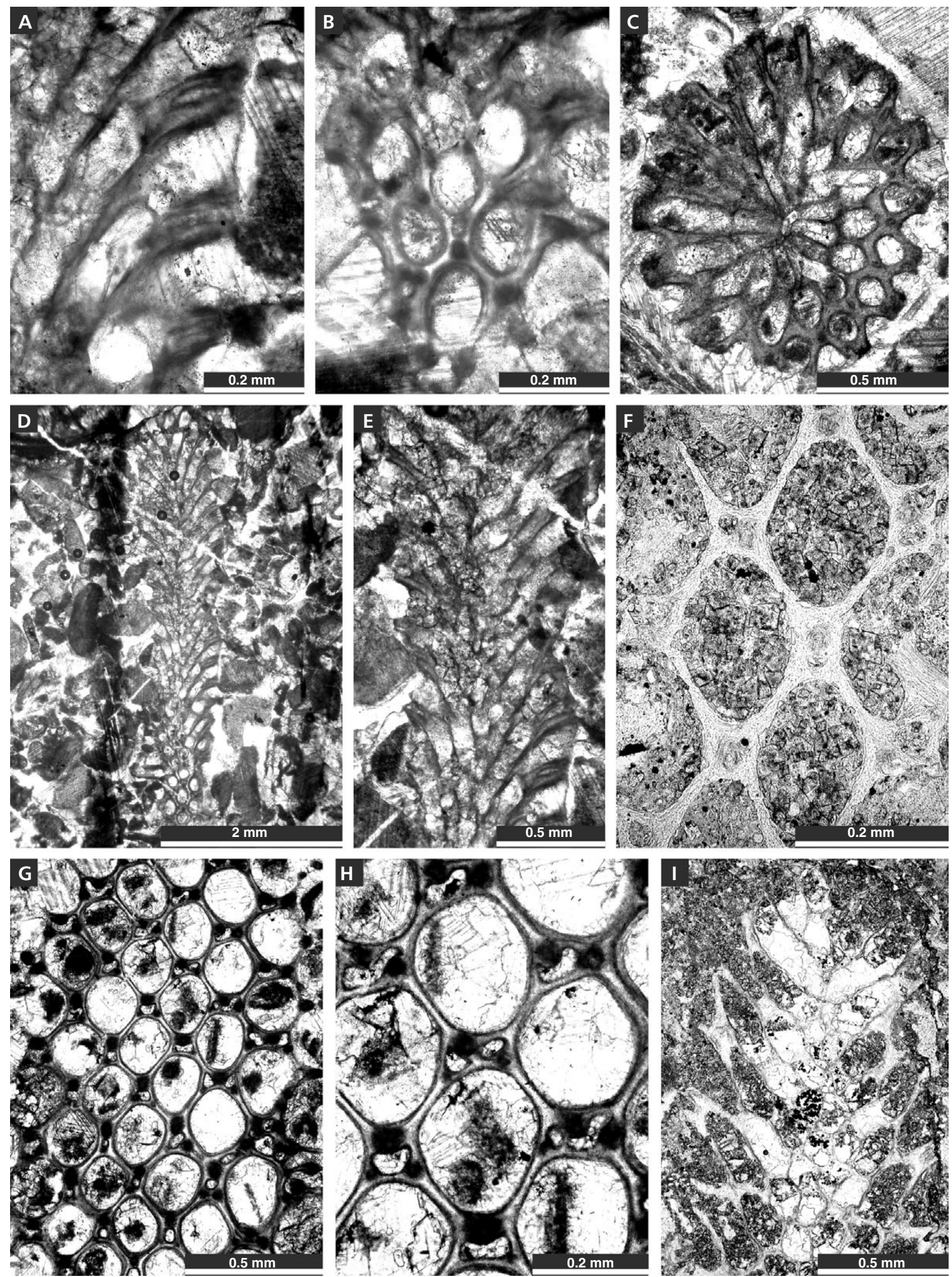
Table 5. Measurements of Nikiforovella dinantia sp. nov. Abbreviations as in Table 1.

\begin{tabular}{|c|c|c|c|c|c|c|c|}
\hline & $\mathrm{F}$ & $\mathrm{N}$ & $X$ & SD & $\mathrm{CV}$ & MIN & MAX \\
\hline Branch width, mm & 6 & 6 & 1.04 & 0.144 & 13.85 & 0.90 & 1.26 \\
\hline Exozone width, mm & 6 & 6 & 0.29 & 0.052 & 18.40 & 0.23 & 0.36 \\
\hline Endozone width, mm & 6 & 6 & 0.47 & 0.043 & 9.23 & 0.42 & 0.54 \\
\hline $\begin{array}{l}\text { Autozooecial aperture width, } \\
\mathrm{mm}\end{array}$ & 6 & 24 & 0.11 & 0.014 & 13.47 & 0.08 & 0.13 \\
\hline $\begin{array}{l}\text { Autozooecial aperture spacing } \\
\text { along branch, } \mathrm{mm}\end{array}$ & 6 & 8 & 0.27 & 0.033 & 12.18 & 0.23 & 0.33 \\
\hline $\begin{array}{l}\text { Autozooecial aperture spacing } \\
\text { diagonally, } \mathrm{mm}\end{array}$ & 6 & 8 & 0.19 & 0.020 & 10.53 & 0.15 & 0.22 \\
\hline Acanthostyle diameter, mm & 6 & 14 & 0.03 & 0.007 & 20.20 & 0.025 & 0.05 \\
\hline Metazooecia width, mm & 6 & 18 & 0.03 & 0.007 & 23.28 & 0.02 & 0.04 \\
\hline Acanthostyles per aperture & 6 & 6 & 1.0 & 0 & 0 & 1.0 & 1.0 \\
\hline Metazooecia per aperture & 6 & 6 & 1.5 & 0.548 & 36.52 & 1.0 & 2.0 \\
\hline
\end{tabular}

Table 6. Measurements of Nikiforovella sp. Abbreviations as in Table 1 .

\begin{tabular}{l|c|c|c|c|c|c|c}
\hline & $\mathrm{F}$ & $\mathrm{N}$ & $\mathrm{X}$ & $\mathrm{SD}$ & $\mathrm{CV}$ & $\mathrm{MIN}$ & $\mathrm{MAX}$ \\
\hline $\begin{array}{l}\text { Autozooecial aperture width, } \\
\text { mm }\end{array}$ & 2 & 40 & 0.19 & 0.022 & 11.94 & 0.14 & 0.23 \\
$\begin{array}{l}\text { Autozooecial aperture spacing } \\
\text { along branch, mm }\end{array}$ & 2 & 40 & 0.32 & 0.037 & 11.46 & 0.25 & 0.40 \\
$\begin{array}{l}\text { Autozooecial aperture spacing } \\
\text { diagonally, mm }\end{array}$ & 2 & 40 & 0.22 & 0.029 & 12.95 & 0.15 & 0.30 \\
$\begin{array}{l}\text { Acanthostyle diameter, mm } \\
\text { Metazooecia width, mm }\end{array}$ & 2 & 40 & 0.037 & 0.006 & 15.22 & 0.025 & 0.050 \\
Acanthostyles per aperture & 2 & 40 & 0.034 & 0.009 & 25.60 & 0.018 & 0.050 \\
Metazooecia per aperture & 2 & 25 & 1.2 & 0.408 & 34.02 & 1.0 & 2.0 \\
\hline
\end{tabular}

Description. - Branched colonies, branch width unknown. Autozooecial apertures oval to circular, arranged in regular diagonal rows. Autozooecial diaphragms absent. Metazooecia $0.018-0.050 \mathrm{~mm}$ wide, originating at the base of exozone, 1-2 arranged between longitudinally successive autozooecial apertures. Acanthostyles 0.025 to $0.050 \mathrm{~mm}$ in diameter, $1-3$ arranged between longitudinally successive autozooecial apertures, having distinct hyaline cores and laminated sheaths. Autozooecial walls granular, 0.005 to $0.010 \mathrm{~mm}$ thick in endozone; finely laminated, without visible zooecial boundaries in exozone.

Remarks. - The present material belongs to the genus Nikiforovella because of regular distribution of metazooecia and acanthostyles and regular arrangement of autozooecial apertures implying spiral budding of autozooecia. This species has distinctly larger apertures than the Mississippian species of Nikiforovella. However, the restricted material prevents establishing a new species, therefore this material is described in open nomenclature here. Nikiforo- vella sp. differs from N. alternata Nekhoroshev, 1956 from the Mississippian of Altai, Russia in its larger autozooecial apertures (autozooecial width $0.14-0.23 \mathrm{~mm} \mathrm{vs} 0.08$ to $0.12 \mathrm{~mm}$ in N. alternata). Nikiforovella sp. differs from N. gracilis Ernst \& Herbig, 2010 in its larger autozooecial apertures (autozooecial width $0.14-0.23 \mathrm{~mm}$ vs 0.08 to $0.14 \mathrm{~mm}$ in $N$. gracilis), and in having 1-2 metazooecia rather than 1-5 metazooecia between apertures in the latter species.

Occurrence. - Pont-de-Scay, Belgium; uppermost Famennian, Comblain-au-Pont Formation.

\section{Discussion}

The bryozoan fauna from the middle and uppermost Famennian deposits of southern Belgium is very specific. It presents seven bryozoans from that four species and one genus are new. Middle Famennian Trepostomata sp. indet shows morphology not previously recorded in Palaeozoic bryozoans. Nonetheless, further material is required to reach a better identification.

Analysis of the generic composition shows predominance of cosmopolitan taxa over endemic taxa. The bryozoan genera Pseudobatostomella and Nikiforovella show a significant geological range from the Devonian to Permian. The genus Dyscritella is known from Devonian to Triassic strata worldwide. Among these genera, Nikiforovella displays the widest geographic distribution during the Famennian. Representatives of this genus are known from the upper Famennian of Germany, Transbaikalia, Kuznetsk Basin, Southern Urals and from the lower part of Famennian of Kazakhstan (Nekhoroshev 1932, Trizna 1958, Troizkaya 1979, Popeko 2000, Ernst \& Herbig 2010, Tolokonnikova 2011, Tolokonnikova et al. 2014, Ernst et al. submitted).

Dyscritella occurs in the upper Famennian deposits of Germany and Mongolia (Ariunchimeg 2000, Ernst \& Herbig 2010, Tolokonnikova et al. 2014), whereas Pseudobatostomella is known from the upper Famennian of Transbaikalia and Kazakhstan (Nekhoroshev 1956, Popeko 2000).

Comparison between the uppermost Famennian bryozoans faunas occurring in the Dinant Synclinorium and those from the Avesnois (northern France), which is the historical type area of the Strunian (Streel et al. 2006), cannot be undertaken due to the lack of recent data. Dehée (1929) briefly discussed and illustrated some species present in the Etrœugnt Formation (e.g. Mistiaen et al. 2013), which is the westernwards time-equivalent of the Comblain-au-Pont Formation, but modern studies are required to give a full account of the bryozoan diversity in this formation. 


\section{Conclusions}

The present paper provides the first data on middle to uppermost Famennian bryozoans of southern Belgium. The studied fauna is represented by seven bryozoans, including three new species of cosmopolitan genera Pseudobatostomella, Nikiforovella and Dyscritella, and one new genus Nikiforovastylus. In the upper Famennian close palaeobiogeographical connections can be traced between Belgium and Germany. Further studies are needed to assess the diversity of the Devonian bryozoans of the Namur-Dinant Basin, notably those from the lower Famennian but especially from the Middle Devonian and Frasnian mixed siliciclastic-carbonate succession of this area in which facies favourable to bryozoans are more developed.

\section{Acknowledgements}

Andrej Ernst thanks the Deutsche Forschungsgemeinschaft (DFG) for financial support (project ER 278/6.1). Part of work is performed according to the Russian Government Program of Competitive Growth of Kazan Federal University. This study is a contribution to the IGCP 596 "Mid-Palaeozoic climate and biodiversity". We are grateful to Ernest H. Gilmour and Patrick N. Wyse Jackson for their critical review.

\section{References}

Anstey, R.L. \& Perry, T.G. 1970. Biometric procedures in taxonomic studies of Paleozoic bryozoans. Journal of Paleontology 44, 383-398.

ARIUNCHIMEG, Y. 2000. The first finds of Famennian bryozoans in Mongolia. Paleontologicheskii zhurnal 2000(1), 45-48. [in Russian]

Armstrong, J. 1970. Zoarial microstructures of two Permian species of the bryozoan genus Stenopora. Palaeontology 13(4/4), 581-587.

Astrova, G.G. 1965. Morphology, history of development and systematics of the Ordovician and Silurian Bryozoa. Trudy Paleontologicheskogo instituta Akademii nauk SSSR 106, 1-432. [in Russian]

Astrova, G.G. \& Morozova, I.P. 1956. About systematics of the Order Cryptostomata. Doklady Akademii nauk SSSR 110(4), 661-664. [in Russian]

Belanger, I., Delaby, S., Delcambre, B., Ghysel, P., HenneBert, M., Laloux, M., Marion, J.-M., Mottequin, B. \& Pingot, J.-L. 2012. Redéfinition des unités structurales du front varisque utilisées dans le cadre de la nouvelle Carte géologique de Wallonie (Belgique). Geologica Belgica 15, 169-175.

BÉThune, P. DE 1954. Carte géologique de Belgique (échelle 1/500.000). Atlas de Belgique, planche 8. Académie royale de Belgique, Brussels.

Blake, D.B. 1973. Acanthopore ultrastructure in the Palaeozoic bryozoan family Rhabdomesidae, 221-229. In LARwood,
G.P. (ed.) Living and Fossil Bryozoa. Academic Press, London.

BlaKe, D.B. 1983. Introduction in the Suborder Rhabdomesina, 530-549. In RoBIson, R.A. (ed.) Treatise on Invertebrate Paleontology. Part G (1): Bryozoa (revised). Geological Society of America \& University of Kansas Press, Boulder.

BorG, F. 1926. Studies on Recent cyclostomatous Bryozoa. Zoologiska Bidrag från Uppsala 10, 181-507.

BouckAert, J., Ziegler, W. \& ThOREZ, J. 1965. Conodont stratigraphy of the Famennian Stage. Mémoires pour servir à l'Explication des Cartes géologiques et minières de la Belgique 5, 1-62.

Bultynck, P. \& Dejonghe, L. 2002. Devonian lithostratigraphic units (Belgium). Geologica Belgica 4, 39-69.

Casier, J.-G., Lebon, A., Mamet, B. \& Préat, A. 2005. Ostracods and lithofacies close to the Devonian-Carboniferous boundary in the Chanxhe and Rivage sections, northeastern part of the Dinant Basin. Bulletin de l'Institut royal des Sciences naturelles de Belgique 75, 95-126.

Chevalier, E. \& Aretz, M. 2005. A microbe-bryozoan reef from the middle Viséan of the Namur Syncline (Engihoul quarry). Geologica Belgica 8, 109-119.

ConiL, R. 1964. Localités et coupes types pour l'étude du Tournaisien inférieur (Révision des limites sous l'aspect micropaléontologique). Académie Royale de Belgique, Classe des Sciences, Mémoires in- $4^{\circ}\left(2^{\text {nd }}\right.$ series) $15(4), 1-87$.

ConIL, R. 1968. Le calcaire carbonifère depuis le Tn1a jusqu' au V2a. Annales de la Société géologique de Belgique 90, 687-726.

Conil, R., Dreesen, R., Lentz, M.A., Lys, M. \& Plodowski, G. 1986. The Devonian-Carboniferous transition in the FrancoBelgian basin with reference to foraminifera and brachiopods. Annales de la Société géologique de Belgique 109, 19-26.

DehÉE, R. 1929. Description de la faune d'Etroeungt (faune de passage du Dévonien au Carbonifère). Mémoires de la Société géologique de France (nouvelle série) 11, 1-62.

Demanet, F. 1938. La Faune des Couches de passage du Dinantien au Namurien dans le synclinorium de Dinant. Mémoires de Musée Royal d'Histoire Naturelle de Belgique, 84, 1-201.

Demanet, F. 1958. Contribution à l'étude du Dinantien de la Belgique. Mémoires de l'Institut royal des Sciences naturelles de Belgique 141, 1-152.

Denayer, J., Poty, E., Marion, J.-M. \& Mottequin, B. 2012. Lower and Middle Famennian (Upper Devonian) rugose corals from southern Belgium and northern France. Geologica Belgica 15, 273-283.

DessiLly, E. 1961. Les bryozoaires dévoniens de la Belgique. Le genre Canutrypa Bassler. Bulletin de l'Institut royal des Sciences naturelles de Belgique 37(9), 1-12.

DessiLly, E. 1967. Les bryozoaires dévoniens de la Belgique. La présence du genre "Phylloporina" dans le Couvinien de la Belgique. Bulletin de l'Institut royal des Sciences naturelles de Belgique 43(3), 1-6.

Dessilly, E. \& KRAüsel, W. 1962. Les bryozoaires dévoniens de la Belgique. La découverte des genres Hemitrypa et Semicoscinium. Bulletin de l'Institut royal des Sciences naturelles de Belgique 38(20), 1-5. 
Dessilly, E. \& Kraüsel, W. 1963. Les bryozoaires dévoniens de la Belgique. Speotrypa, nouveau genre du Couvinien de la Belgique. Bulletin de l'Institut royal des Sciences naturelles de Belgique 39(31), 1-13.

Dreesen, R. 1978. Position stratigraphique de la Formation de Souverain-Pré dans le Synclinorium de Dinant et dans le Bassin de la Vesdre. Service géologique de Belgique, Professional Paper 150, 1-74.

Dreesen, R., Bless, M.J.M., Conil, R., Flajs, G. \& Laschet, C. 1985. Depositional environment, paleocology and diagenetic history of the "Marbre rouge à crinoïdes de Baelen" (Late Upper Devonian, Verviers Synclinorium, Eastern Belgium). Annales de la Société géologique de Belgique 108, 311-359.

Dreesen, R., Marion, J.-M. \& Mottequin, B. 2013. The Red Marble of Baelen, a particular historical building stone with global geological importance and local use. Geologica Belgica 16, 179-190.

Dumont, A.H. 1855. Carte géologique de l'Europe. Ed. E. Noblet, Paris \& Liège.

DunAEVA, N.N. 1964. The Early Carboniferous trepostome fauna from the Donetsk Basin. Trudy Instituta geologii Akademii nauk Ukrainskoi SSR, Seriya stratigraphiya i paleontologiya 48(2), 104-141. [in Russian]

Dunaeva, N.N. \& Morozova, I.P. 1967. Peculiarities of development and systematical position of some Upper Paleozoic Trepostomata. Paleontologicheskii zhurnal 4, 86-94. [in Russian]

EhrenberG, C.G. 1831. Symbolae Physicae, seu Icones et descptiones Corporum Naturalium novorum aut minus cognitorum, quae ex itineribus per Libyam, Aegiptum, Nubiam, Dongalaam, Syriam, Arabiam et Habessiniam, studia annis 1820-25, redirent. Pars Zoologica, 4, Animalia Evertebrata exclusis Insectis. 10 pls. Mittler, Berlin.

ERnST, A. \& Gorgi, M.N. 2013. Lower Permian bryozoan faunas from Kalmard area, central Iran. Neues Jahrbuch für Geologie und Paläontologie, Abhandlungen 268(3), 275-324. DOI 10.1127/0077-7749/2013/0330

Ernst, A. \& Herbig, H.-G. 2010. Stenolaemate bryozoans from the Latest Devonian (Uppermost Famennian) of Western Germany. Geologica Belgica 13(3), 173-182.

Ernst, A., Königshof, P. \& SchÄFER, P. 2009. Unusual skeletal morphology and systematic description of a new Devonian cryptostome bryozoan from Morocco. Paläontologische Zeitschrift 83, 449-457. DOI 10.1007/s12542-009-0028-2

Ernst, A., Tolokonnikova, Z. \& Herbig, H.-G. Uppermost Famennian bryozoans from Ratingen, Rhenish Massif (Germany). Geologica Belgica (submitted).

GiRTY, G. H. 1911. New genera and species of Carboniferous fossils from the Fayettville Shale of Arkansas. Annals of the New York Academy of Sciences 20, 189-238. DOI 10.1111/j.1749-6632.1910.tb55149.x

Goryunova, R.V. 1975. Permian bryozoans of the Pamir. Trudy Paleontologicheskogo instituta Akademii nauk SSSR 148, 1-125. [in Russian]

Groessens, E. 1975. Preliminary range chart of conodont biozonation in the Belgian Dinantian, 1-193. In BOUCKAERT, J. \& STreel, M. (eds) International Symposium on Belgian micropaleontological limits from Emsian to Viséan, Namur 1974. Geological Survey of Belgium, Brussels.
Hageman, S.J. 1993. Effects of nonnormality on studies of the morphological variation of a rhabdomesine Bryozoan, Streblotrypa (Streblascopora) prisca (Gabb \& Horn). The University of Kansas Paleontological Contributions 4, 1-13.

HaRvell, C.D. 1984. Predator-induced defense in a marine bryozoan. Science 224, 1357-1359.

DOI 10.1126/science.224.4655.1357

HaRvell, C.D. 1992. Inducible defences and allocation shifts in a marine bryozoan. Ecology 73(5), 1567-1576.

DOI 10.2307/1940010

Kaiser, S.I., Becker, R.T., Steuber, T. \& Aboussalam, S.Z. 2011. Climate-controlled mass extinctions, facies, and sealevel changes around the Devonian-Carboniferous boundary in the eastern Anti-Atlas (SE Morocco). Palaeogeography, Palaeoclimatology, Palaeoecology 310, 340-364.

DOI 10.1016/j.palaeo.2011.07.026

KAISIN, F. JR. 1942. Les Bryozoaires fenestrellinidés et acanthocladiidés du Tournaisien de la Belgique. Mémoires de l'Institut géologique de l'Université de Louvain 13, 92-141.

KonincK, L.-G. DE 1842-1844. Description des animaux fossiles qui se trouvent dans le terrain carbonifère de Belgique. 650 pp. Dessain, Liège.

LAUWERS, A.S. 1992. Growth and diagenesis of cryptalgal-bryozoan buildups within a mid-Visean (Dinantian) cyclic sequence, Belgium. Annales de la Société géologique de Belgique 115, 187-213.

LeE, G.W. 1912. The British Carboniferous Trepostomata. Memoirs of the Geological Survey of Great Britain 1(3), 135-195.

LeEs, A. 1988. The Waulsortian buildups of the Dinant area, 177-186. In Herbosch, A. (ed.) International association of Sedimentologists, $9^{\text {th }}$ European regional meeting Leuven 1988, Excursion guidebook.

LEES, A. 2006. Waulsortian. Geologica Belgica 9, 151-155.

MaILlieux, E. 1933. Terrains, roches et fossiles de la Belgique. 217 pp. Patrimoine du Musée d'Histoire naturelle de Belgique, Brussels.

Maziane, N., Higgs, K.T. \& Streel, M. 1999. Revision of the late Famennian miospore zonation scheme in eastern Belgium. Journal of Micropaleontology 18, 17-25.

DOI 10.1144/jm.18.1.17

Maziane-Serraj, N., Hartkopf-Fröder, C., Streel, M. \& ThoREZ, J. 2007. Palynomorph distribution and bathymetry in the Chanxhe section (eastern Belgium), reference for the neritic late to latest Famennian transition (Late Devonian). Geologica Belgica 10, 170-175.

Mistiaen, B., Brice, D., Devleeschouwer, X., Hubert, B.L.M., Khatir, A., Mottequin, B., Nicollin, J.-P. \& Poty, E. 2013. Le "Calcaire d'Etrœungt" dans les coupes historiques d'Etrœugnt et d'Avesnelles (Avesnois, Nord, France). Annnales de la Société géologique du Nord (2ème série) 20, 43-51.

Modzalevskaya, Y.A. 1960. Novye devonskie trepostomaty vostochnogo Zabaikalya [New trepostomata from the Eastern Zabaikalye], 260-263. In MARKowsKiI, B.P. (ed.) Novye vidy drevnikh rastenii $i$ zhivotnykh [New species of fossil plants and animals], volume 1. VSEGEI, Moscow. [in Russian]

MorozovA, I.P. 1960. Devonskie mshanki Minusinskikh i Kuznetskoy kotlovin [Devonian Bryozoa of the Minusinsk 
and Kuznetsk Basins]. Trudy Paleontologischeskogo instituta Akademii nauk SSSR 86, 1-207. [in Russian]

Mottequin, B. 2008. Late middle Frasnian to early Famennian (Late Devonian) strophomenid, orthotetid and athyridid brachiopods from southern Belgium. Journal of Paleontology 82, 1052-1073. DOI 10.1666/07-086.1

Nekhoroshev, V.P. 1932. Die Bryozoen des deutschen Unterkarbons. Abhandlungen der Preussischen Geologischen Landesanstalt, Neue Folge 141, 1-74.

Nekhoroshev, V.P. 1948. Devonian Bryozoa of the Altai (Paleontologiya SSSR: Devonskie mshanki Altaya). Paleontology of the USSR 3,1-172. [in Russian]

NekHorosheV, V.P. 1956. Nizhnekamennougolnye mshanki Altaya i Sibiri [Lower Carboniferous Bryozoa of Altai and Siberia]. Trudy Vsesoyuznogo nauchno-issledovatelskogo instituta (VSEGEI), n. s. 13, 1-420. [in Russian]

NikiforovA, A.I. 1948. Nizhne-kamennougolnye mshanki Karatau [Lower Carboniferous Bryozoa of Karatau]. 53 pp. Akademiya nauk Kazakhskoi SSR, Alma-Ata. [in Russian]

PopeKo, L.I. 2000. Carboniferous of the Mongol-Okhotsk orogenic belt. 124 pp. Dalnauka, Vladivostok. [in Russian]

Pоту, E. 1999. Famennian and Tournaisian recoveries of shallow water Rugosa following late Frasnian and late Strunian major crisis, southern Belgium and surrounding areas, Hunan (South China) and the Omolon region (NE Siberia). Palaeogeography, Palaeoclimatology, Palaeoecology 154, 11-26. DOI 10.1016/S0031-0182(99)00084-X

Poty, E., Aretz, M. \& Denayer, J. 2011. Field trip 3: Uppermost Devonian and Lower Carboniferous of Southern Belgium. Kölner Forum für Geologie und Paläontologie 20, 99-150.

Poty, E., Devuyst, F.-X. \& Hance, L. 2006. Upper Devonian and Mississippian foraminiferal and rugose coral zonations of Belgium and Northern France, a tool for Eurasian correlations. Geological Magazine 146, 829-857. DOI 10.1017/S0016756806002457

Poty, E., Hance, L., Lees, A. \& Hennebert, M. 2002. Dinantian lithostratigraphic units (Belgium). Geologica Belgica 4, 69-94.

SAlÉE, A. 1919. Les 'Fistulipora' globuleux du Dévonien moyen de la Belgique (note préliminaire). Bulletin de la Société belge de Géologie, de Paléontologie et d'Hydrologie 29, 46-48.

SARTENAER, P. 1972. De l'importance stratigraphique des rhynchonellides famenniens situés au-dessus de la Zone à Ptychomaletoechia dumonti (Gosselet, J., 1877). Première note: Cavatisinurostrum n. gen. Bulletin de l'Institut royal des Sciences naturelles de Belgique, Sciences de la Terre 48(2), $1-22$.

Shishova, N.A. 1965. The systematic position and size of the family Hyphasmoporidae. Paleontologicheskii zhurnal 2, 55-65. [in Russian]

Simpson, G.B. 1895. Handbook of the genera of the North American Palaeozoic Bryozoa. Annual report New York State Geology 14, 403-669.
Streel, M., Brice, D. \& Mistiaen, B. 2006. Strunian. Geologica Belgica 9, 105-109.

TAVEnER-SMith, R. 1975. The phylogenetic affinities of fenestelloid bryozoans. Palaeontology 18(1), 1-17.

Tolokonnikova, Z. 2011. The first data on bryozoans from Devonian-Carboniferous boundary beds of the Southern Urals (Zigan and Sikaza sections), 156-158. Biostratigraphy, paleogeography and events in Devonian and Lower Carboniferous (SDS/IGCP 596 joint field meeting). Publishing House of SB RAS, Novosibirsk.

Tolokonnikova, Z., Ernst, A. \& Herbig, H.-G. 2014. Famennian (Upper Devonian) bryozoans from borehole Velbert 4, Rhenish Slate Massif (Germany). Neues Jahrbuch für Geologie und Paläontologie, Abhandlungen 273(1), 25-44. DOI 10.1127/0077-7749/2014/0414

Thorez, J., Streel, M., Bouckaert, J. \& Bless, M.J.M. 1977. Stratigraphie et paléogéographie de la partie orientale du Synclinorium de Dinant (Belgique) au Famennien supérieur: un modèle de bassin sédimentaire reconstitué par analyse pluridisciplinaire sédimentologique et micropaléontologique. Mededelingen Rijks Geologische Dienst, New Series 28, $17-32$.

Thorez, J., Dreesen, R. \& Streel, M. 2006. Famennian. Geologica Belgica 9(1-2), 27-45.

TRIznA, V.B. 1958. Rannekamennougolnye mshanki Kuznetzkoi kotloviny [Early Carboniferous bryozoans of the Kuznets depression]. Trudy Vsesoyuznogo neftanogo nauchno-issledovatel'skogo geologo-razvedochnogo instituta 122, 1-436. [in Russian]

TroizKaYA, T.D. 1979. Bryozoans of the meistorovi horizon of Central Kazakhstan. Paleontologicheskii zhurnal 1979(4), 31-39. [in Russian]

Ulrich, E.O. 1882. American Palaeozoic Bryozoa. The Journal of the Cincinnati Society of Natural History 5, 121-175, 233-257.

UlRICH, E.O. 1890. Palaeozoic Bryozoa. Palaeontology of Illinois. Geological Survey of Illinois 8, Part II, Section VI, 283-688.

ViNe, G.R. 1884. Fourth report of the Committee consisting of Dr. H.R. Sorby and Mr. G.R. Vine, appointed for the purpose of reporting on fossil Polyzoa. Report of the Fifty-third meeting of the British Association for the Advancement of Science London (Southport, 1883), 161-209. John Murray, London.

WeBer, H.M. \& WySE JACKSON, P.N. 2006. Bryozoen, 101-105. In Deutsche Stratigraphische Kommission (ed.) Stratigraphie von Deutschland VI. Unterkarbon (Mississippium). Schriftenreihe der Deutschen Gesellschaft für Geowissenschaften 41 .

WysE JACKSON, P.N. 2006. Bryozoa from Waulsortian buildups and their lateral facies (Mississippian, Carboniferous) in Belgium and Ireland. Courier Forschungsinstitut Senckenberg 257, 149-160. 